\title{
Striatal Muscarinic Receptors Promote Activity Dependence of Dopamine Transmission via Distinct Receptor Subtypes on Cholinergic Interneurons in Ventral versus Dorsal Striatum
}

\author{
Sarah Threlfell, ${ }^{1 \star}$ Michael A. Clements, ${ }^{1 \star}$ Tansi Khodai, ${ }^{1,2}$ Ilse S. Pienaar, ${ }^{1}$ Richard Exley, ${ }^{1}$ Jürgen Wess, ${ }^{3}$ \\ and Stephanie J. Cragg ${ }^{1}$ \\ ${ }^{1}$ Department of Physiology, Anatomy and Genetics, University of Oxford, Oxford OX1 3PT, United Kingdom, ${ }^{2}$ Department of Pharmacology, University of \\ Oxford, Oxford OX1 3QT, United Kingdom, and ${ }^{3}$ Laboratory of Bioorganic Chemistry, National Institute of Diabetes and Digestive and Kidney Diseases, \\ Bethesda, Maryland 20892
}

Striatal dopamine (DA) and acetylcholine (ACh) regulate motivated behaviors and striatal plasticity. Interactions between these neurotransmitters may be important, through synchronous changes in parent neuron activities and reciprocal presynaptic regulation of release. How DA signaling is regulated by striatal muscarinic receptors (mAChRs) is unresolved; contradictory reports indicate suppression or facilitation, implicating several $\mathrm{mAChR}$ subtypes on various neurons. We investigated whether $\mathrm{mAChR}$ regulation of DA signaling varies with presynaptic activity and identified the $\mathrm{mAChRs}$ responsible in sensorimotor- versus limbic-associated striatum. We detected DA in real time at carbon fiber microelectrodes in mouse striatal slices.

Broad-spectrum mAChR agonists [oxotremorine-M, APET (arecaidine propargyl ester tosylate)] decreased DA release evoked by low-frequency stimuli (1-10 Hz, four pulses) but increased the sensitivity of DA release to presynaptic activity, even enhancing release by high frequencies (e.g., $>25 \mathrm{~Hz}$ for four pulses). These bidirectional effects depended on ACh input to striatal nicotinic receptors (nAChRs) on DA axons but not GABA or glutamate input. In caudate-putamen ( $\mathrm{CPu}$ ), knock-out of $\mathrm{M}_{2}-$ or $\mathrm{M}_{4}-\mathrm{mAChRs}$ (not $\mathrm{M}_{5}$ ) prevented $\mathrm{mAChR}$ control of $\mathrm{DA}$, indicating that $\mathrm{M}_{2}$ - and $\mathrm{M}_{4}-\mathrm{mAChRs}$ are required. In nucleus accumbens (NAc) core or shell, $\mathrm{mAChR}$ function was prevented in $\mathrm{M}_{4}$-knock-outs, but not $\mathrm{M}_{2}$ - or $\mathrm{M}_{5}$-knock-outs.

These data indicate that striatal mAChRs, by inhibiting ACh release from cholinergic interneurons and thus modifying nAChR activity, offer variable control of DA release probability that promotes how DA release reflects activation of dopaminergic axons. Furthermore, different coupling of striatal $\mathrm{M}_{2} / \mathrm{M}_{4}$-mAChRs to the control of DA release in $\mathrm{CPu}$ versus NAc suggests targets to influence DA/ACh function differentially between striatal domains.

\section{Introduction}

Mesostriatal dopaminergic neurons and striatal cholinergic interneurons (ChIs) play important roles in the signaling and learning of motivational significance and action selection (Schultz, 1998; Calabresi et al., 2000; Partridge et al., 2002; Schultz, 2002; Morris et al., 2004; Pisani et al., 2007). Interactions between striatal acetylcholine (ACh) and dopamine (DA) are important and have been suggested to be mediated via correlated changes in neuron activities, reciprocal presynaptic regulation of

\footnotetext{
Received Nov. 12, 2009; revised Dec. 27, 2009; accepted Jan. 4, 2010.

This work was supported by Parkinson's Disease Society Grants G-0808 and G-4067, a Biotechnology and Biological Sciences Research Council-Eli Lilly Collaborative Award in Science and Engineering, and an International Brain Research Organization International Studentship (I.S.P.). We thank Dr. K. Jennings for critica reading of this manuscript.

*S.T. and M.A.C. contributed equally to this work.

Correspondence should be addressed to Dr. Stephanie J. Cragg, Department of Physiology, Anatomy and Genetics, Sherrington Building, University of 0xford, 0xford 0X1 3PT, UK. E-mail: stephanie.cragg@dpag.ox.ac.uk. DOI:10.1523/JNEUROSCI.5620-09.2010

Copyright $\odot 2010$ the authors $\quad 0270-6474 / 10 / 303398-11 \$ 15.00 / 0$
}

neurotransmitter release, and through postsynaptic interactions (e.g., in corticostriatal plasticity) (Calabresi et al., 2000; Zhou et al., 2002; Centonze et al., 2003; Pisani et al., 2003; Morris et al., 2004; Cragg, 2006). To comprehend DA and ACh actions in striatum, it is essential to understand their interactions.

Muscarinic receptors ( $\mathrm{mAChRs}$ ) are densely expressed in striatum where they have long been suggested to influence striatal DA release. However, the data are contradictory, and the mechanisms unresolved. Poor ligand selectivity has made it difficult to define the mAChR type(s) involved (Wess et al., 2007). Some studies report that mAChRs enhance DA release (Lehmann and Langer, 1982; Raiteri et al., 1984; Schoffelmeer et al., 1986; Xu et al., 1989; De Klippel et al., 1993; Zhang et al., 2002b; Grilli et al., 2008), whereas some report suppression (Schoffelmeer et al., 1986; Kemel et al., 1989; Xu et al., 1989; De Klippel et al., 1993; Kudernatsch and Sutor, 1994; Zhang et al., 2002b; Tzavara et al., 2004). For release of $\left[{ }^{3} \mathrm{H}\right] \mathrm{DA}$ evoked by high $\left[\mathrm{K}^{+}\right]$, different receptors have been proposed to mediate inhibition (e.g., $\mathrm{M}_{3^{-}}$ mAChRs) versus facilitation (e.g., $M_{4} / M_{5}-m A C h R s$ ), through 
mechanisms involving modulation of GABA tone at $\mathrm{GABA}_{\mathrm{A}}$ receptors (Zhang et al., 2002b). However, $\mathrm{GABA}_{\mathrm{A}}$ receptors have not been identified on DA terminals (Fujiyama et al., 2000). Other mechanisms or sites must be involved.

Dopaminergic neurons may possess $\mathrm{M}_{5}$-mAChRs in midbrain for modulation by mesopontine afferents (Vilaró et al., 1990; Weiner et al., 1990; Forster et al., 2002), but there is currently no anatomical evidence that $\mathrm{mAChRs}$ are located on dopaminergic axons. Striatal ChIs in contrast, which release ACh and regulate DA release via $\beta 2$-subunit-containing nicotinic AChRs $\left(\beta 2^{\star}\right.$-nAChRs) on dopaminergic axons, express $\mathrm{M}_{2}$ and/or $\mathrm{M}_{4}-\mathrm{mAChRs}$ (Yan and Surmeier, 1996; Bernard et al., 1998; Alcantara et al., 2001; Ding et al., 2006; Bonsi et al., 2008). These $\mathrm{M}_{2} / \mathrm{M}_{4}-\mathrm{mAChRs}$ regulate ChI activity and ACh release (Raiteri et al., 1984; Schoffelmeer et al., 1986; Yan and Surmeier, 1996) and might therefore gate $\beta 2^{\star}-\mathrm{nAChR}$ function by controlling ACh availability. Since $\beta 2^{\star}$-nAChRs inhibit or facilitate DA release depending on the frequency of presynaptic activity in DA axons (Rice and Cragg, 2004; Zhang and Sulzer, 2004; Cragg, 2006), mAChRs on ChIs might also regulate DA release probability in a bidirectional manner.

We used cyclic voltammetry at carbon fiber microelectrodes in striatal slices to identify the mAChR control of endogenous DA release during a range of evoked activity that spans the physiological frequencies seen in dopaminergic neurons in vivo. We identify a variable, activity-dependent control of DA release by mAChRs on ChIs and, using mAChR subtype-null mice, identify roles for different receptor subtype(s) in dorsal versus ventral striatum.

\section{Materials and Methods}

Slice preparation and voltammetry. We used either CD1 mice (20-40 g; Harlan) or, for studies examining mAChR subtype function, C57BL/ 6NTac mice (wild-type, $\mathrm{M}_{2}{ }^{-1-}, \mathrm{M}_{4}{ }^{-1-}$, and $\mathrm{M}_{5}{ }^{-1-}$ mice; 30-44 g). The generation of the mAChR mutant mice has been described previously (Gomeza et al., 1999a,b; Yamada et al., 2001). All mutant mouse strains had been backcrossed for 10 generations onto the C57BL/6NTac background (Taconic).

Mouse striatal slices, $300 \mu \mathrm{m}$ thick, were prepared in a coronal plane (unless stated otherwise) containing both nucleus accumbens (NAc) and caudatoputamen $(\mathrm{CPu})$ using previously described methods (Rice and Cragg, 2004; Exley et al., 2008). Slices were cut using a vibratome (VT1000S or VT1200S; Leica) in ice-cold HEPES-based buffer containing the following (in mM): $120 \mathrm{NaCl}, 5 \mathrm{KCl}, 20 \mathrm{NaHCO}_{3}, 6.7 \mathrm{HEPES}$ acid, $3.3 \mathrm{HEPES}$ salt, $2 \mathrm{CaCl}_{2}, 2 \mathrm{MgSO}_{4}, 1.2 \mathrm{KH}_{2} \mathrm{PO}_{4}$, and 10 glucose, saturated with $95 \% \mathrm{O}_{2} / 5 \% \mathrm{CO}_{2}$. Slices were maintained at room temperature in HEPES-based Ringer's solution for $\geq 1 \mathrm{~h}$ before transferal to the recording chamber. The slices were equilibrated with the superfusion medium of the recording chamber at $30-32^{\circ} \mathrm{C}$ for a minimum of $30 \mathrm{~min}$ before the beginning of the experiment. The superfusion medium was a bicarbonate-buffered artificial CSF (aCSF) maintained at $30-32^{\circ} \mathrm{C}$ and contained the following (in mM): $124 \mathrm{NaCl}, 3.7 \mathrm{KCl}, 26 \mathrm{NaHCO}_{3}, 2.4$ $\mathrm{CaCl}_{2}, 1.3 \mathrm{MgSO}_{4}, 1.3 \mathrm{KH}_{2} \mathrm{PO}_{4}$, and 10 glucose saturated with $95 \%$ $\mathrm{O}_{2} / 5 \% \mathrm{CO}_{2}$. Superfusion flow rate was $\sim 1.5 \mathrm{ml} / \mathrm{min}$.

Extracellular DA concentration $\left([\mathrm{DA}]_{\mathrm{o}}\right)$ was monitored using fastscan cyclic voltammetry (FCV) with 7 - to $10-\mu \mathrm{m}$-diameter carbon fiber microelectrodes (tip length, $\sim 50-100 \mu \mathrm{m}$; fabricated in-house) and a Millar voltammeter (Julian Millar, Barts and the London School of Medicine and Dentistry, London, UK) as described previously (Cragg, 2003; Rice and Cragg, 2004; Exley et al., 2008). The scanning voltage was a triangular waveform $(-0.7$ to $+1.3 \mathrm{~V}$ range vs $\mathrm{Ag} / \mathrm{AgCl})$ at a scan rate of $800 \mathrm{~V} / \mathrm{s}$ and sampling frequency of $8 \mathrm{~Hz}$. Evoked currents were attributed to DA by comparison of the potentials for peak oxidation and reduction currents with those of DA in calibration media $(+500-600$ and -200 $\mathrm{mV}$ vs $\mathrm{Ag} / \mathrm{AgCl}$, respectively). Currents sampled at the DA oxidation peak potential were measured in each voltammogram from baselines on which the oxidation current was superimposed, to provide profiles of
$[D A]_{0}$ versus time. This procedure minimizes inclusion of contributions from other electroactive and nonelectroactive species to the neurotransmitter oxidation current (Venton et al., 2003). Electrodes were calibrated in 1-2 $\mu \mathrm{M}$ DA in all experimental media. Calibration solutions were made immediately before use from stock solutions of DA stored in $0.1 \mathrm{M}$ $\mathrm{HClO}_{4}$. Electrode sensitivity to DA was between 10 and $30 \mathrm{nA} / \mu \mathrm{M}$.

Electrical stimulation. DA release was evoked by a surface, bipolar concentric electrode $(25-\mu \mathrm{m}$-diameter Pt/Ir; FHC) positioned $\sim 100 \mu \mathrm{m}$ from the recording electrode as previously described (Cragg and Greenfield, 1997; Cragg, 2003; Rice and Cragg, 2004). Stimulus pulses (200 $\mu$ s duration) were generated out-of-phase with FCV scans and were applied at the lowest currents $(0.5-0.7 \mathrm{~mA})$ that generated maximal DA release with a single stimulus pulse of this duration. This protocol synchronizes release from multiple synapses (Cragg, 2003) and minimizes site-to-site variability in evoked $[\mathrm{DA}]_{\mathrm{o}}$ and ensures that release on a population level as closely as possible resembles release from any one synapse. Release evoked by a single local stimulus using this approach is $\mathrm{Ca}^{2+}$ dependent and TTX sensitive (i.e., action potential dependent).

DA release evoked by these stimulus protocols and timescales is not modulated by endogenous glutamate or GABA at ionotropic receptors (Avshalumov et al., 2003; Cragg, 2003), or DA itself at $\mathrm{D}_{2}$ receptors (Phillips et al., 2002; Schmitz et al., 2002; Cragg, 2003) but is modulated by ACh. Endogenous levels of ACh tonically activate presynaptic $\beta 2^{\star}$ nAChRs on DA axons independently of the external stimulation (Zhou et al., 2001; Rice and Cragg, 2004; Zhang and Sulzer, 2004) and influence DA release probability variably depending on stimulus frequency (Zhou et al., 2001; Rice and Cragg, 2004; Zhang and Sulzer, 2004).

Any changes in extracellular ACh levels caused by the electrical stimulus do not appear to play a significant role in these effects (Zhou et al., 2001; Rice and Cragg, 2004; Zhang and Sulzer, 2004) and do not appear to be necessary for the effects of $\mathrm{mAChR}$ agonists reported here. In pilot experiments, we used distal stimulation to limit the contribution made by evoked $\mathrm{ACh}$ release to the changes in $[\mathrm{DA}]_{\mathrm{o}}$ detected at a remote recording electrode. In those experiments, striatal recording sites in parasaggital mouse slices were chosen in which DA release could be elicited by distal stimulation at distances of up to $1000 \mu \mathrm{m}$ from the recording electrode along a ventrocaudal-to-dorsorostral axis (in line with ascending DA pathways) but not by stimulation along an orthogonal axis. Evoked $[D A]_{0}$ were much lower at the remote site of release as expected for a lower evoked current density (Exley et al., 2008), but importantly activity-dependent changes in DA release were seen in response to ACh ligands that were similar to those observed when using local stimulation (data not shown).

Experimental design and analysis. Stimuli were repeated at a minimum of $2.5 \mathrm{~min}$ intervals, to ensure consistent release. Stimuli were administered in one of two patterns. In some experiments, stimuli consisted of trains of four pulses at a range of frequencies $(1-100 \mathrm{~Hz})$ in randomized order. These frequencies span the full range of dopaminergic neuron firing frequencies reported in vivo. In other experiments, we used a simplified protocol whereby single pulses (one pulse or $1 \mathrm{p}$ ) were alternated with four pulses (4p) at $100 \mathrm{~Hz}$. This comparison most powerfully demonstrates activity-dependent effects of ACh at $\beta 2^{*}$-nAChRs on DA release, as published previously (Rice and Cragg, 2004; Exley et al., 2008).

The $\mathrm{mAChR}$ control of DA release was explored in $\mathrm{CPu}$, NAc core, and NAc shell. These different regions have discrete roles [e.g., in different components of action selection (salience, $\mathrm{CPu}$, or reward value, $\mathrm{NAc}$ )] and are differently affected during pathological disorders including Parkinson's disease and drug addiction. Thus, improved insights into the distinct mechanisms that control DA function in each of these territories could advance insights into discrete pharmacological therapies. Recordings in $\mathrm{CPu}$ were made in the dorsal quartile of $\mathrm{CPu}$, those in NAc core were immediately ventral to the anterior commissure, and those in NAc shell were ventromedial to the lateral ventricle (see supplemental Fig. S1, available at www.jneurosci.org as supplemental material). Where experimental outcome was similar in $\mathrm{CPu}$ and NAc, data from one representative region are illustrated to avoid redundancy.

Data were acquired and analyzed using Axoscope 10.2 (Molecular Devices) or Strathclyde Whole Cell Program (University of Strathclyde, Glasgow, UK) and locally written programs. Data are means \pm SEM, and 
the sample size, $n$, is the number of observations. The number of animals in each data set is $\geq 3$. Data are expressed as extracellular concentration of dopamine $\left([\mathrm{DA}]_{\mathrm{o}}\right)$, or as $[\mathrm{DA}]_{\mathrm{o}}$ normalized to release by a single pulse in a given condition, as specified. All experimentally induced changes in $[\mathrm{DA}]_{\text {o }}$ were attributable to changes in release rather than uptake, by analysis of decay phases of extracellular recordings (data not shown). Comparisons for differences in means were assessed by one- or two-way ANOVA and post hoc multiple-comparison $t$ tests (Tukey or Bonferroni) or unpaired $t$ tests using GraphPad Prism. Concentration-response curves were generated with GraphPad Prism 4 using nonlinear regression to a sigmoidal dose-response curve (variable slope). Other curve-fitting and linear regressions were performed in GraphPad Prism or SigmaPlot.

Drugs. Arecaidine propargyl ester tosylate (APET), D-AP5, 4-(8methyl-9H-1,3-dioxolo[4,5-h][2,3]benzodiazepin-5-yl)-benzenamine hydrochloride (GYKI 52466 hydrochloride), ( $S$ )- $\alpha$-methyl-4-carboxyphenylglycine [( $S)-\mathrm{MCPG}]$, oxotremorine-M (Oxo-M), picrotoxin, and saclofen were purchased from Tocris Bioscience or Ascent Scientific. Atropine, dihydro- $\beta$-erythroidine ( $\mathrm{DH} \beta \mathrm{E})$, himbacine, telenzepine, tropicamide, and all other reagents were purchased from Sigma-Aldrich. Drugs were dissolved in distilled water, or aqueous alkali [( $S)-\mathrm{MCPG}]$, aqueous acid (GYKI 52466 hydrochloride), or ethanol (picrotoxin, tropicamide, himbacine) to make stock aliquots at $1000-10,000 \times$ final concentrations, and stored at $-20^{\circ} \mathrm{C}$ until required. Stock aliquots were diluted with oxygenated aCSF to final concentration immediately before use.

\section{Results}

\section{Activation of striatal mAChRs enhances activity dependence of dopamine release}

We explored how $\mathrm{mAChR}$ activation modifies DA release evoked by a range of stimulus frequencies $(1-100 \mathrm{~Hz}$; four pulses) in $\mathrm{CPu}$ and in NAc (core). It is important to explore DA neurotransmission across a range of stimulus frequencies for several reasons. First, dopaminergic neurons vary their firing frequency widely in vivo: dopaminergic neurons switch from low-frequency activity $(\leq 5 \mathrm{~Hz})$ to brief bursts of high frequency $(\sim 15-100 \mathrm{~Hz})$ in response to events of motivational significance (e.g., reward predictions) (Schultz, 1986; Hyland et al., 2002; Schultz, 2002; Brischoux et al., 2009; Matsumoto and Hikosaka, 2009). Second, the control of neurotransmitter release by a given neuromodulatory receptor will depend on the influence of its effector mechanisms given the various other driving forces that dynamically govern release probability. For example, the regulation of DA by nicotinic cholinergic receptors $\left(\beta 2^{*}-\mathrm{nAChRs}\right)$ on DA axons is variable depending on firing frequency in DA axons (Rice and Cragg, 2004; Zhang and Sulzer, 2004; Exley and Cragg, 2008; Exley et al., 2008).

In control conditions, evoked [DA $]_{\mathrm{o}}$ varied slightly but significantly with stimulus frequency by up to $130 \pm 8 \%(\mathrm{CPu})$ or $175 \pm 6 \%$ (NAc core) of release by a single pulse, according to an inverted $U$ (Gaussian) relationship (Fig. 1) (two-way ANOVAs, $p<0.001 ; n=9-14$ ) as described previously (Exley et al., 2008). This limited dependence of $[\mathrm{DA}]_{\mathrm{o}}$ on stimulus frequency is characteristic of DA release in this protocol in which the probability of striatal DA release at the first pulse in any train is high, and in which short-term synaptic depression of release limits re-release at successive pulses within a burst (Cragg, 2003, 2006; Rice and Cragg, 2004). The broad-spectrum mAChR agonists, oxotremorine-M $(10 \mu \mathrm{M})$, or APET $(10 \mu \mathrm{M})$ (data not shown), modified evoked $[\mathrm{DA}]_{\mathrm{o}}$ in a frequency-dependent manner in $\mathrm{CPu}$ (Fig. 1a) and in NAc (Fig. 1c) (two-way ANOVAs, $p<0.001 ; n=9-14$ ). For trains of four pulses, [DA] ovoked by frequencies $\leq 25 \mathrm{~Hz}$ was decreased compared with control conditions by up to $\sim 50 \%$, whereas $[\mathrm{DA}]_{\mathrm{o}}$ evoked by frequencies $>25 \mathrm{~Hz}$ was enhanced, by up to $\sim 50 \%$, in CPu (Fig. 1a) and in NAc (Fig. 1c) (Bonferroni's post hoc $t$ tests). These frequency-dependent effects of mAChR agonists significantly enhanced the sensitivity of DA release to frequency, which varied according to a sigmoidal function (Fig. 1b,d).

To confirm that $\mathrm{mAChR}$ drug effects in striatum were attributable to an action at mAChRs, we tested whether a broadspectrum $\mathrm{mAChR}$ antagonist, atropine $(2 \mu \mathrm{M})$, could reverse the responses to oxotremorine-M $(10 \mu \mathrm{M})$. We used a simplified stimulus protocol consisting of a single stimulus pulse (release equals $1 \mathrm{~Hz}$ ) alternated with a burst of four pulses at $100 \mathrm{~Hz}$. This protocol is a powerful tool to demonstrate activity-dependent control of DA release, as seen previously by $\beta 2^{\star}-n A C h R s$ and $\mu / \delta$-opioid receptors (Rice and Cragg, 2004; Zhang and Sulzer, 2004; Britt and McGehee, 2008; Exley et al., 2008). Oxotremorine-M $(10 \mu \mathrm{M})$ decreased release by $1 \mathrm{p}$, enhanced release by $4 \mathrm{p} / 100 \mathrm{~Hz}$ (in keeping with effects shown in Fig. 1 for stimuli of 1 and 100 $\mathrm{Hz}$ ) (two-way ANOVAs and post hoc $t$ tests, $p<0.05 ; n=9$ ) and thus increased the contrast in $[\mathrm{DA}]_{\mathrm{o}}$ evoked by bursts versus single pulses in $\mathrm{CPu}$ (Fig. 1e,f) and NAc (data not shown). These effects were reversed by atropine (Fig. $1 e, f$ ), which restored $[\mathrm{DA}]_{\mathrm{o}}$ to levels not different from pre-oxotremorine-M control conditions (two-way ANOVAs, $p>0.05 ; n=9$ ). Conversely, previous application of atropine prevented any subsequent action of oxotremorine-M (Fig. 1g,h) (CPu; NAc, not illustrated). Atropine alone did not modify evoked $[\mathrm{DA}]_{\mathrm{o}}$ in $\mathrm{CPu}$ (Fig. $\left.1 g, h\right)$ or NAc (not illustrated) (two-way ANOVAs, $p>0.05 ; n=9$ ), consistent with a lack of tonic activity of $\mathrm{mAChRs}$ under these conditions as reported previously (Yan and Surmeier, 1996; Bennett and Wilson, 1999).

\section{Striatal $\mathrm{mAChRs}$ govern DA release via regulation of $\mathrm{ACh}$ tone at nicotinic AChRs}

These activity-dependent effects of mAChRs on DA release are strikingly similar to the published effects of inhibition of striatal $\beta 2^{\star}$-nAChRs (Rice and Cragg, 2004; Zhang and Sulzer, 2004; Exley et al., 2008). Normally, endogenous striatal ACh released by tonically active ChIs maintains a resting ACh tone at striatal $\beta 2^{*}$ nAChRs located on DA axons. This ACh tone ensures that initial DA release probability by a single stimulus pulse is high (Zhou et al., 2001; Rice and Cragg, 2004), and as a result short-term depression of DA re-release during burst activity is great, limiting additional release (Cragg, 2003; Rice and Cragg, 2004). Block or desensitization of striatal $\beta 2^{\star}$-nAChRs decreases initial DA release probability for a single pulse and relieves short-term depression to permit DA release by successive pulses within a burst (Rice and Cragg, 2004; Zhang and Sulzer, 2004; Exley et al., 2008). Since mAChRs are not found on DA axons but are expressed on ChIs where they can inhibit neuron activity and/or the release of striatal ACh (Raiteri et al., 1984; Schoffelmeer et al., 1986; Yan and Surmeier, 1996; Ding et al., 2006; Bonsi et al., 2008), we tested whether mAChRs located on ChIs could be responsible indirectly for the $\mathrm{mAChR}$ regulation of DA release.

To test whether mAChRs regulate DA transmission indirectly via manipulation of $\mathrm{ACh}$ tone at $\beta 2^{\star}$-nAChRs on DA axons, we used $\mathrm{DH} \beta \mathrm{E}(100 \mathrm{~nm})$ to inhibit $\beta 2^{\star}$-nAChRs. DH $\beta E$ modified $[\mathrm{DA}]_{\mathrm{o}}$ evoked by single pulses and bursts $(4 \mathrm{p} / 100 \mathrm{~Hz})$ in an activity-dependent manner in CPu (Fig. $2 a, b)$ and NAc $(n=9$; two-way ANOVAs, $p<0.001$; NAc, not illustrated) as previously reported (Rice and Cragg, 2004; Exley et al., 2008). Moreover, $\mathrm{DH} \beta \mathrm{E}$ completely precluded any subsequent effects of oxotremorine-M $(10 \mu \mathrm{M})$ on DA release in either region (Fig. $2 a, b)(\mathrm{CPu}$; NAc, not illustrated) (two-way ANOVAs, $p>0.05$; $n=9$ ). These data reveal that DA release is not modulated by 

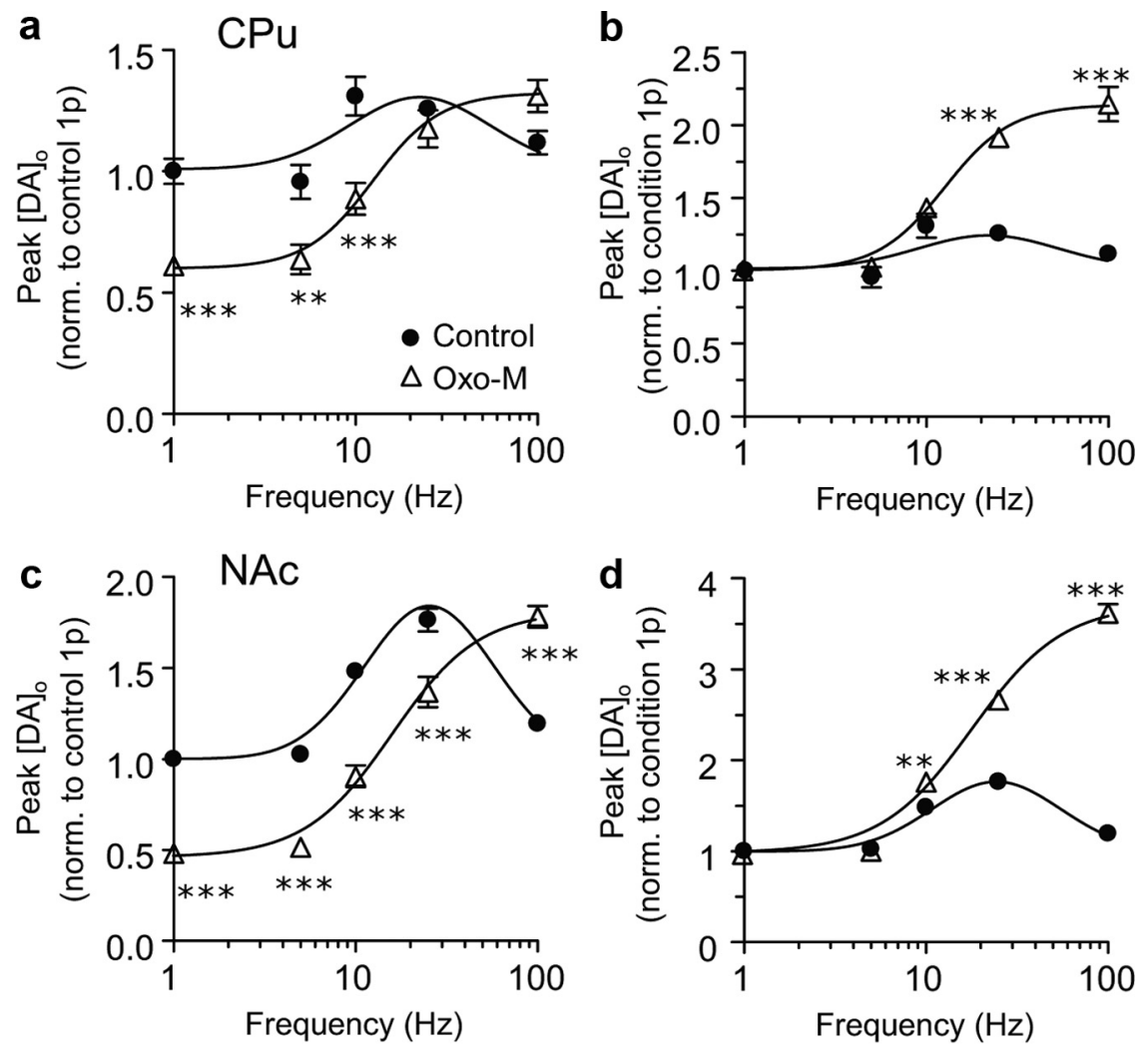

e
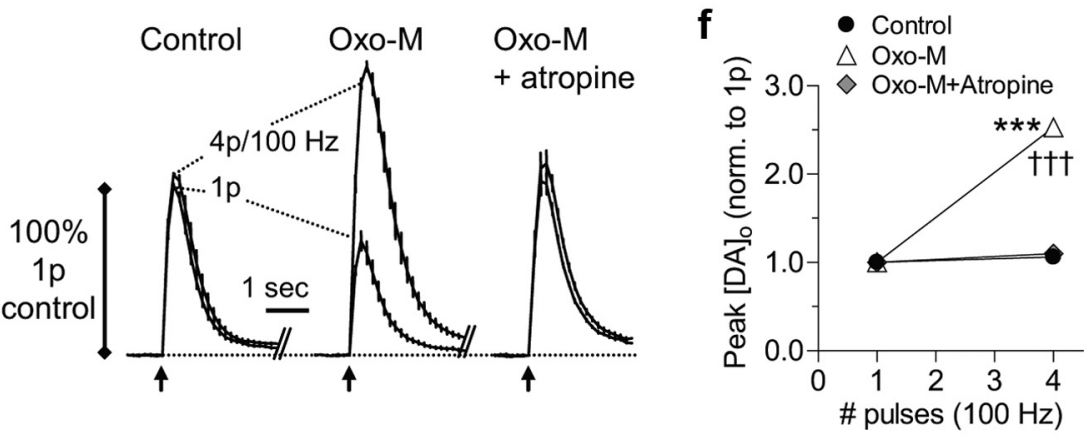

g

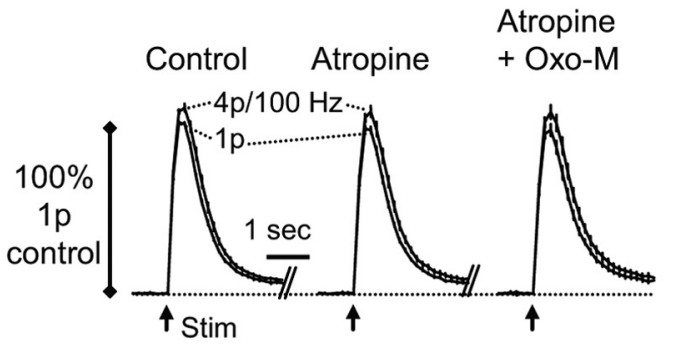

mAChRs if there is no tonic activity at $\beta 2^{*}$-nAChRs and indicate that these mAChRs are located not on DA axons but, rather, on ChIs, where via their effects on ACh release they limit $\mathrm{ACh}$ activation of $\beta 2^{\star}$-nAChRs on DA axons. We also reversed the order of application of these drugs to assess the extent to which mAChR activation could limit ACh action at $\beta 2^{\star}$-nAChRs (seen with $\mathrm{DH} \beta \mathrm{E}$ ), whether partially or fully. Typically, the effects of oxotremorine-M (10 $\mu \mathrm{M})$ on $[\mathrm{DA}]_{\mathrm{o}}$ evoked by single pulses and $4 \mathrm{p} / 100$ $\mathrm{Hz}$ bursts were not enhanced further by the addition of $\mathrm{DH} \beta \mathrm{E}$ in either $\mathrm{CPu}$ (Fig. $2 c, d)$ (two-way ANOVAs, $p>0.05 ; n=9$ ) or NAc (not illustrated). On a few occasions (in $\mathrm{CPu}$ only), there were limited additional effects of $\mathrm{DH} \beta \mathrm{E}(1 \mu \mathrm{M})$ when applied after oxotremorine-M $(\sim 25 \%$ additional change), but the combined effect on DA release was the same as that seen with $\mathrm{DH} \beta \mathrm{E}$ alone (data not shown). Together, these data indicate that $\mathrm{mAChR}$ activation regulates DA release indirectly by reducing ACh release from ChIs to levels of ACh that typically are below a threshold required for activation of $\beta 2^{*}$ nAChRs on dopaminergic axons (for schematic illustration of these interactions, see supplemental Fig. S2, available at www.jneurosci.org as supplemental material).

Note that the tonic activation by endogenous ACh of $\beta 2^{\star}$-nAChRs (Fig. $2 a, b$ ) (Zhou et al., 2001; Rice and Cragg, 2004; Zhang and Sulzer, 2004) but not mAChRs (Fig. $1 g$ ) is consistent with the greater affinity of ACh for nAChRs than mAChRs, which typically is three orders of magnitude greater for $\beta 2^{\star}$-nAChRs $\left(K_{\mathrm{i}}\right.$ for $\beta 2^{\star}$ nAChRs, $\sim 10 \mathrm{~nm}$ ) (de Fiebre et al., 1995; Whiteaker et al., 1998) than for mAChRs (e.g., $K_{\mathrm{i}}$ for $\mathrm{M}_{2}$ - and $\mathrm{M}_{4}$-mAChRs, $~ 30$ $\mu \mathrm{M})$ (Jakubik et al., 1997).

Striatal glutamate and GABA do not normally play significant roles in regulating DA release probability during discrete subsecond stimuli (Cragg, 2003; Rice and Cragg, 2004; Zhang and Sulzer, 2004; Exley et al., 2008). However, since striatal GABAergic and glutamatergic transmission can be modulated by mAChR activation (Sugita et al., 1991; Calabresi et al., 1998b,c, 2000; Koós and Tepper, 2002; Zhang et al., 2002b; Pakhotin and Bracci, 2007), it was important to establish whether the effects of $\mathrm{mAChR}$ activation on DA release were mediated via activation of normally quiescent GABA/glutamate interactions with striatal DA. Application of a mixture of antagonists for GABA $\left(\mathrm{GABA}_{\mathrm{A}}\right.$ : picrotoxin, $100 \mu \mathrm{M}$; $\mathrm{GABA}_{\mathrm{B}}$ : saclofen, 50 
$\mu \mathrm{M})$ and glutamate receptors [AMPA: GYKI 52466, $10 \mu \mathrm{M}$; NMDA: D-AP5, $50 \mu \mathrm{M}$; mGlu: (S)-MCPG, $200 \mu \mathrm{M}$ ] did not prevent the effects of oxotremorine-M $(10 \mu \mathrm{M})$ on single-pulse- and burst-evoked $[\mathrm{DA}]_{\mathrm{o}}$ in either $\mathrm{CPu}$ (Fig. 2e,f) (two-way ANOVAs, $p<0.001 ; n=9$ ) or NAc (not illustrated). These data rule out a contribution of GABA and glutamate inputs to $\mathrm{mAChR}$ control of DA release identified here.

\section{Striatal $\mathrm{mAChR}$ subtype involved in regulation of $\mathrm{DA}$ release differs in $\mathrm{CPu}$ and NAc}

The data reported here indicate that striatal ACh autoreceptors on ChIs, and not $\mathrm{mAChRs}$ on dopaminergic, glutamate, or GABA afferents, are responsible for a dynamic regulation of DA release probability, which is operated via a change in $\mathrm{ACh}$ levels at $\beta 2^{\star}$-nAChRs (see supplemental Fig. S2, available at www.jneurosci.org as supplemental material). Striatal ChIs express $\mathrm{M}_{2}$-mAChRs $\left(\mathrm{M}_{2} \mathrm{Rs}\right)$ and/or $\mathrm{M}_{4}$ mAChRs $\left(\mathrm{M}_{4} \mathrm{Rs}\right)$ (Hersch et al., 1994; Yan and Surmeier, 1996; Bernard et al., 1998; Alcantara et al., 2001; Zhang et al., 2002a; Ding et al., 2006). We assessed which $\mathrm{mAChRs}$ regulate DA transmission in $\mathrm{CPu}$ and in NAc using pharmacological approaches as well as $\mathrm{mAChR}$ subtypespecific knock-out mice.

We assessed potential differences in the mAChR mechanisms in $\mathrm{CPu}$ and NAc by comparing the concentration dependence of the effects of oxotremorine-M $(10 \mathrm{~nm}$ to $20 \mu \mathrm{M})$ on DArelease. Oxotremorine-M decreased single-pulse-evoked $[D A]_{0}$ but enhanced $[D A]_{o}$ evoked by trains of four pulses $(100 \mathrm{~Hz})$ in a concentration-dependent manner in $\mathrm{CPu}$ and NAc core (Fig. 3) (two-way ANOVAs, $p<0.001 ; n=9$ ). However, higher concentrations of oxotremorine-M were required to modify DA release probability in $\mathrm{CPu}$ (Fig. 3a,b) than in NAc (Fig. 3c-e) (two-way ANOVAs, post hoc Bonferroni's $t$ test; $n=9$ ): DA function in NAc can be discretely modulated by striatal $\mathrm{mAChR}$ agonists at concentrations that do not modify DA release in $\mathrm{CPu}$ (e.g., $10^{-7} \mathrm{M}$ Oxo-M). These data suggest that different mechanisms (e.g., different types of mAChRs) might mediate the mAChR regulation of DA in NAc and in CPu.

To explore further the mAChR subtypes responsible in each region, we next tested whether antagonists with purported broad $M_{2} / M_{4}$ subtype preference prevent the $m A C h R$ regulation of DA release in both $\mathrm{CPu}$ and in NAc core. At concentrations reported to be relatively selective for $\mathrm{M}_{2} / \mathrm{M}_{4}$-group receptors (Karlsson et al., 2000), himbacine (50 nM) completely prevented the effects of $1 \mu \mathrm{M}$ oxotremorine-M on $[\mathrm{DA}]_{\mathrm{o}}$ evoked by $1 \mathrm{p}$ and $4 \mathrm{p} / 100 \mathrm{~Hz}$ and partially prevented the effects of $10 \mu \mathrm{M}$ oxotremorine, in both CPu (Fig. $4 a-d$ ) and in NAc (Fig. $4 e-h$ ) $(p<0.001$ for comparison of himbacine plus $10 \mu \mathrm{M}$ Oxo-M vs $10 \mu \mathrm{M}$ Oxo-M alone). Similarly, tropicamide (30-100 nM), another $\mathrm{M}_{2} / \mathrm{M}_{4}$-preferring antagonist, reversed the effects of oxotremorine-M $(10 \mu \mathrm{M})$ (data not shown). These data are con- sistent with a major role for $\mathrm{M}_{2} / \mathrm{M}_{4}$ subtypes in both $\mathrm{CPu}$ and NAc. However, most antagonists tested, including those for other families of mAChRs, could antagonize these effects of oxotremorine-M if sufficiently high concentrations of antagonist were used (e.g., $\mathrm{M}_{1}$-preferring antagonist, telenzepine, at $3 \mu \mathrm{M}$ ) (data not shown). Current ligands for mAChRs have poor selectivity for any single subtype of $\mathrm{mAChR}$ receptor, and, therefore, delineation of subtypes using only a pharmacological approach is difficult (Wess et al., 2007).

To delineate further the striatal mAChR subtype governing DA release, we explored the $\mathrm{mAChR}$ control of DA release in striata from mice null for $\mathrm{M}_{2^{-}}, \mathrm{M}_{4^{-}}$, or $\mathrm{M}_{5}$-mAChRs. In these experiments, we explored the control of DA release in each genotype across a full range of frequencies for four pulse trains (1-100 $\mathrm{Hz}$ ), in dorsal $\mathrm{CPu}, \mathrm{NAc}$ core, and NAc shell. In each experiment, we explored the effect of activating mAChRs with Oxo-M (10 $\mu \mathrm{M}$ ), before we subsequently blocked any remaining endogenous $\mathrm{ACh}$ action at $\beta 2^{\star}$-nAChRs using the $\mathrm{nAChR}$ antagonist $\mathrm{DH} \beta \mathrm{E}$ $(1 \mu \mathrm{M})$. This protocol allowed us to be able to distinguish loss of $\mathrm{mAChR}$ regulation of $\beta 2^{*}$-nAChR control of DA release from any other confounding loss or variation in $\beta 2^{\star}$-nAChR function.

In dorsal $\mathrm{CPu}$ in all genotypes, evoked $[\mathrm{DA}]_{\mathrm{o}}$ in control conditions exhibited only a weak dependence on frequency (Fig. 5), 

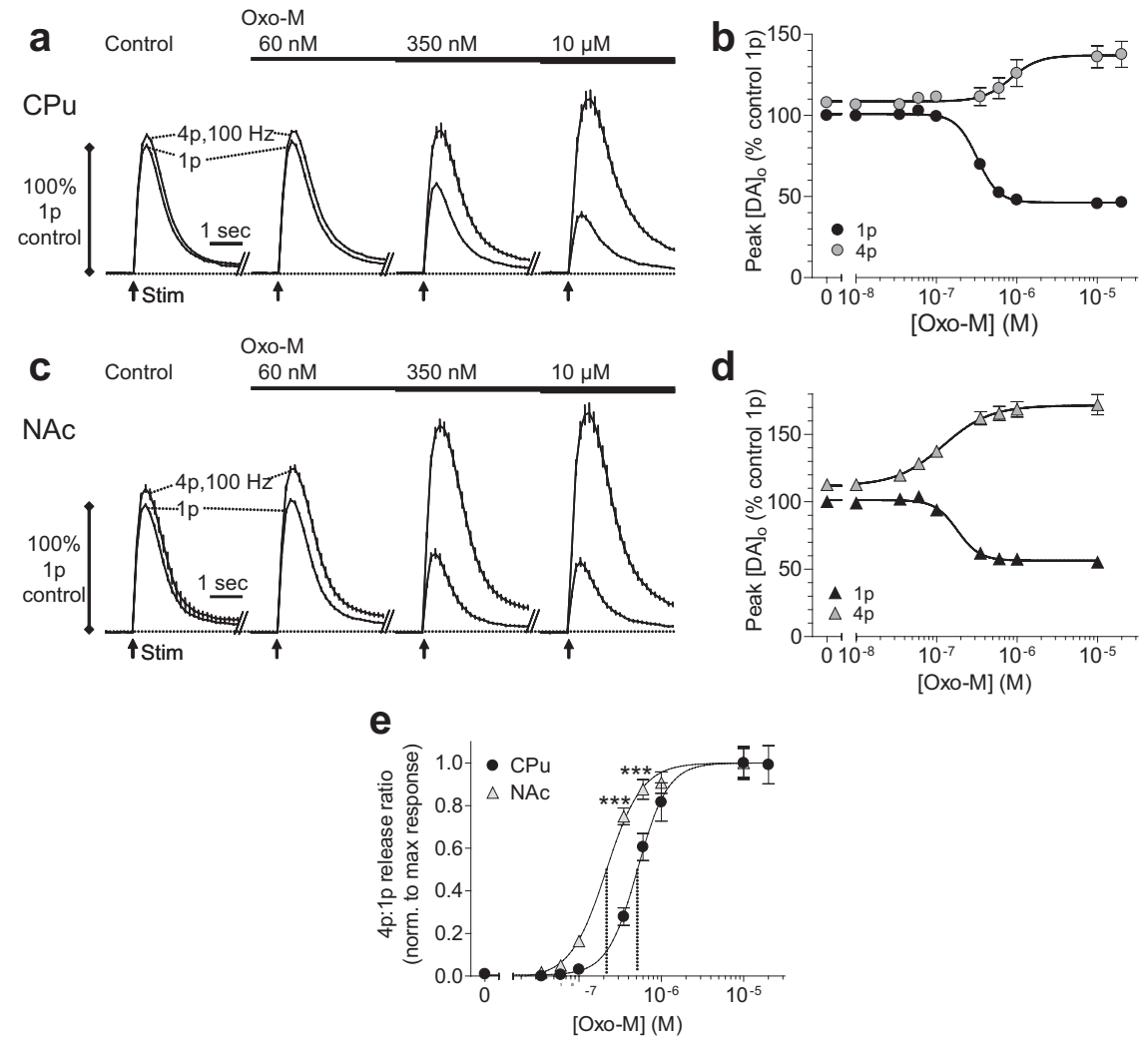

Figure 3. Differences in mAChR control in dorsal versus ventral striatum. $\boldsymbol{a}, \boldsymbol{c}$, Profiles of mean $[D A]_{0} \pm$ SEM versus time after stimuli (arrows) of either a single pulse (1p) or a high-frequency burst ( $4 \mathrm{p} ; 100 \mathrm{~Hz}$ ) in control (left) and in increasing concentrations of oxotremorine-M (Oxo-M) in $\mathrm{CPu}(\boldsymbol{a})$ and NAc (c). Data are normalized to peak [DA] $]_{0}$ released by $1 \mathrm{p}$ in controls. Post hoc Bonferroni's $t$ tests for burst versus single pulse are all $p<0.001, n=9 . \boldsymbol{b}, \boldsymbol{d}$, Mean peak [DA $]_{0} \pm$ SEM evoked by $1 p$ (black fill) and $4 \mathrm{p} / 100 \mathrm{~Hz}$ (gray fill) plotted versus $0 \times 0-\mathrm{M}$ concentration for $\mathrm{CPu}(\boldsymbol{b})$ and NAc (d). One-way ANOVAs for effect of $0 \times 0-M, p<0.001$. Curve fits are sigmoidal concentration-response curves, $R^{2}>0.87 .1$ release: Hill slopes, $-3.30(\boldsymbol{b}),-3.10(\boldsymbol{d}) ; \mathrm{C}_{50}, 320 \mathrm{~nm}(\boldsymbol{b})$, $180 \mathrm{~nm}(\boldsymbol{d})$. $4 \mathrm{p}$ release: Hill slopes, $2.50(\boldsymbol{b}), 1.48(\boldsymbol{d}) ; \mathrm{EC}_{50}, 840 \mathrm{~nm}(\boldsymbol{b}), 120 \mathrm{~nm}(\boldsymbol{d})$. $\boldsymbol{e}$, Effect of $0 x 0-\mathrm{M}$ on relative release by burst versus single pulses (4p:1p release ratio) in (Pu (circles) and NAC (triangles). Data are normalized to maximum response for comparison between regions. Curve fits (solid lines) are sigmoidal concentration-response curves, $R^{2}>0.88$. $\mathrm{EC}_{50}$ values (dotted lines) are significantly different from one another ( $p<0.001 ;(\mathrm{Pu}, 510 \mathrm{~nm} ; 95 \%$ confidence interval range, $450-580 \mathrm{~nm} ; \mathrm{NAc}, 210$ nм; $95 \%$ confidence interval range, $180-250 \mathrm{~nm}$ ). Asterisks (*) indicate significant difference in $4 \mathrm{p}: 1 \mathrm{p}$ ratio response in (Pu versus NAc, in post hoc Bonferroni's $t$ tests, ${ }^{* * *} p<0.001 ; n=9$.

as seen previously in wild types [CD-1 (Fig. 1); C57BL/6J (Exley et al., 2008)]. In wild-type controls for mAChR-knock-out mice (C57BL/6NTac), oxotremorine-M (10 $\mu \mathrm{M})$ significantly modified $[\mathrm{DA}]_{\mathrm{o}}$ in an activity-dependent manner that increased the sensitivity of DA release to activity and increased the range of [DA $]_{\mathrm{o}}$ (Fig. 5a) (two-way ANOVA, $p<0.001 ; n=9$ ), as seen previously in other wild types (CD-1) (Fig. 1). Subsequent inhibition of $\beta 2^{\star}$-nAChRs with $\mathrm{DH} \beta \mathrm{E}(1 \mu \mathrm{M})$ only slightly, but not significantly, modified evoked $[\mathrm{DA}]_{\mathrm{o}}$ further (Fig. $5 a$ ). $\mathrm{M}_{5^{-}}$ mAChR knock-outs $\left(\mathrm{M}_{5} \mathrm{R} \mathrm{KO}\right)$ were similar: oxotremorine-M modified evoked $[\mathrm{DA}]_{\mathrm{o}}$ in an activity-dependent manner that was only slightly modified further by $\mathrm{DH} \beta \mathrm{E}$ (Fig. $5 b$ ) (two-way ANOVA, $p<0.001 ; n=9)$. In contrast, knock-out of the $\mathrm{M}_{2}$ mAChR $\left(\mathrm{M}_{2} \mathrm{R} \mathrm{KO}\right)$ abolished any significant effect of oxotremorine-M on $[\mathrm{DA}]_{\mathrm{o}}$ evoked by any frequency (Fig. $5 c$ ). Subsequent inhibition of $\beta 2^{\star}$-nAChRs, however, significantly modified DA release in an activity-dependent manner (Fig. $5 c$ ) (two-way ANOVA, $p<0.001 ; n=15-18$ ) typical of the normal effects of inhibition of $\beta 2^{*}$-nAChRs (Fig. 2a) (Exley et al., 2008) indicating that, in $\mathrm{M}_{2} \mathrm{R}-\mathrm{KO}$, there is loss of the $\mathrm{mAChR}$ control of $\beta 2^{\star}-\mathrm{nAChR}$ regulation of DA release, rather than a loss of $\beta 2^{\star}$ $\mathrm{nAChR}$ function per se. Greater concentrations of oxotremorine-M
$(50 \mu \mathrm{M})$ did not restore mAChR control of DA release (data not shown). Intriguingly, knock-out of the $\mathrm{M}_{4}$-mAChR $\left(\mathrm{M}_{4} \mathrm{R}-\mathrm{KO}\right)$ had similar outcome to knock-out of the $M_{2} R$. The effects of oxotremorine-M on $[\mathrm{DA}]_{\mathrm{o}}$ were abolished in $\mathrm{M}_{4} \mathrm{R}-\mathrm{KOs}$, whereas effects of subsequent direct inhibition of $\beta 2^{*}$-nAChRs were preserved: $\mathrm{DH} \beta \mathrm{E}$ significantly modified DA release in an activity-dependent manner (Fig. 5d) (two-way ANOVA, $p<$ $0.001 ; n=15-19)$. Greater concentrations of oxotremorine-M alone $(50 \mu \mathrm{M})$ did not reinstate $\mathrm{mAChR}$ control of DA release (data not shown). These data therefore indicate that in $\mathrm{CPu}, \mathrm{M}_{2} \mathrm{Rs}$ and $\mathrm{M}_{4} \mathrm{Rs}$ are both required for $\mathrm{mAChRs}$ on ChIs to regulate DA release (via modulation of ACh action at $\beta 2^{*}-\mathrm{nAChRs}$ as described above).

In NAc in control conditions, in wild type and mAChR knock-outs, evoked $[\mathrm{DA}]_{\mathrm{o}}$ was weakly dependent on frequency in NAc core (Fig. 6) and NAc shell (Fig. 7), as seen previously in NAc core wild types (Fig. 1). However, knock-out of the $M_{4} R$ but not the $M_{2} R$ or $M_{5} R$ prevented $\mathrm{mAChR}$ control of DA release in NAc core (Fig. 6) (two-way ANOVAs, $p<$ $0.001 ; n=12$ ) and NAc shell (Fig. 7) (twoway ANOVA, $p<0.001 ; n=9)$. The effects of inhibiting $\beta 2^{\star}$-nAChRs directly with $\mathrm{DH} \beta \mathrm{E}$ were preserved in all genotypes (Figs. 6, 7). These data indicate normal activity of $\mathrm{ACh}$ at $\beta 2^{\star}$-nAChRs in each genotype, but loss of $\mathrm{mAChR}$ control of this action throughout NAc in $\mathrm{M}_{4}$-KOs.

\section{Discussion}

These data revise our understanding of striatal $\mathrm{mAChR}-\mathrm{DA}$ interactions in several ways. First, we show that striatal mAChRs offer variable, bidirectional control of DA release probability depending on presynaptic activity. These data reconcile previous contradictory findings since striatal mAChRs do not simply suppress or enhance DA release but can do both depending on the frequency of depolarization. Second, this variable $\mathrm{mAChR}$ control of DA release is not via variable striatal neuron types but is via the control of ACh release from striatal ChIs. These mAChRs, by modifying ACh release, powerfully gate the $\beta 2^{*}$-nAChR-regulation of DA release. Third, we show important differences in the $\mathrm{mAChR}$ regulation of DA (and ChIs) in sensorimotor- versus limbic-associated striatum: $\mathrm{mAChR}$ control of DA release in $\mathrm{CPu}$ requires $\mathrm{M}_{2}$ Rs and $\mathrm{M}_{4}$ Rs (but not $\mathrm{M}_{5} \mathrm{Rs}$ ), whereas in NAc, $\mathrm{M}_{4}$ Rs but not $\mathrm{M}_{2} \mathrm{Rs}$ (or $\mathrm{M}_{5} \mathrm{Rs}$ ) are necessary.

\section{Striatal mAChRs enhance activity dependence of DA release via regulation of $\mathrm{ACh}$ tone at nicotinic AChRs}

Activation of striatal mAChRs suppressed DA release by single pulses or low, tonic-like frequencies of presynaptic activity, but enhanced the sensitivity of DA release to frequency, which increased $[\mathrm{DA}]_{\mathrm{o}}$ by higher, burst-like frequencies (absolute 
changes in $[D A]_{o}$ depend on frequency and number of pulses). A similar, activitydependent outcome on DA release probability has been described after the inhibition of striatal $\beta 2^{*}$-nAChRs (or desensitization by nicotine) as follows. Endogenous striatal $\mathrm{ACh}$ is released from tonically active striatal ChIs (Bennett and Wilson, 1999), which maintains ACh tone at $\beta 2^{*}$-nAChRs on dopaminergic axon terminals in the absence of any other stimuli (Zhou et al., 2001). This resting tone ensures that DA release has a high probability of occurring in response to a single stimulus pulse (Zhou et al., 2001; Cragg, 2003; Rice and Cragg, 2004). Short-term synaptic depression follows such DA release and limits re-release by successive pulses within bursts (Abeliovich et al., 2000; Cragg, 2003, 2006; Rice and Cragg, 2004; Zhang and Sulzer, 2004). Block of ACh action at $\beta 2^{*}$-nAChRs decreases DA release probability by single stimuli (Zhou et al., 2001) and, by relieving short-term depression, increases the relative probability of release at subsequent action potentials. The probability of DA release is then proportional to frequency (Rice and Cragg, 2004; Zhang and Sulzer, 2004), as though restored to showing classical, dynamic probability of neurotransmitter release seen at other synapses (for review, see Thomson, 2000).

However, unlike for striatal $\beta 2^{\star}$-nAChRs, there is no anatomical evidence that striatal mAChRs are present on dopaminergic axon terminals to influence DA release directly (Jones et al., 2001; Zhang et al., 2002b; Zhou et al., 2003). In contrast, many other striatal neurons express and are regulated by $\mathrm{mAChRs}$, including striatal ChIs (Bernard et al., 1992, 1998; Yan and Surmeier, 1996; Alcantara et al., 2001; Bonsi et al., 2008), GABAergic interneurons (Koós and Tepper, 2002), GABAergic projection neurons (Weiner et al., 1990; Levey et al., 1991; Calabresi et al., 2000; Yan et al., 2001), and glutamatergic afferents (Sugita et al., 1991; Calabresi et al., 2000; Pakhotin and Bracci, 2007). To date, mAChR regulation of GABA action at $\mathrm{GABA}_{\mathrm{A}}$ receptors has been implicated in the control of DA release in protocols using high $\left[\mathrm{K}^{+}\right]$to evoke $\left[{ }^{3} \mathrm{H}\right] \mathrm{DA}$ release, but given the paucity of $\mathrm{GABA}_{\mathrm{A}}$ receptors on DA terminals (Fujiyama et al., 2000), and the lack of effect of synaptic blockers for GABA/ glutamate on the control of DA release by mAChRs during discrete electrical stimuli, a GABAergic dependence is insufficient to explain the dynamic mAChR modulation of endogenous DA release.

In contrast, the dynamic regulation of endogenous striatal DA release by mAChRs shown here requires ACh tone at $\beta 2^{\star}-n A C h R s$ on DA axons: blockade of ACh input from ChIs to $\beta 2^{\star}-n A C h R s$ precluded effects of $\mathrm{mAChR}$ agonists and vice versa. Striatal ChIs express somatodendritic and axonal mAChRs (Bernard et al., 1992, 1998; Alcantara et al., 2001; Zhang et al., 2002a), which are autoreceptors: oxotremorine-M silences $\mathrm{ChIs}$ and inhibits ACh release (via inhibition of $\mathrm{Ca}_{\mathrm{v}} 2$-type $\mathrm{Ca}^{2+}$ conductances and/or $\mathrm{K}_{\mathrm{v}}^{+}$channel opening) (Raiteri et al., 1984; Schoffelmeer et al., 1986; Yan and Surmeier, 1996; Calabresi et al., 1998a, 2000; Zhang et al., 2002a; Zhou et al., 2003; Ding et al., 2006; Bonsi et al., 2008). Thus, the current data are consistent with mAChR agonists acting at $\mathrm{ACh}$ autoreceptors on ChIs, which inhibit $\mathrm{ACh}$ release, consequently deactivate $\beta 2^{\star}$-nAChRs on dopaminergic axons, and, in turn, increase the sensitivity of DA release to presynaptic depolarization frequency (supplemental Fig. S2, available at www.jneurosci.org as supplemental material). This activity-dependent outcome of mAChRs on DA release reconciles previously conflicting data that report opposite modulation of DA: outcome of mAChR activation will depend on the depolarizing conditions in dopaminergic and cholinergic neurons in any given preparation. Furthermore, endogenous ACh might tonically (or intermittently) control DA release via mAChRs under physiological conditions in vivo, if ACh levels are higher, for 


\section{Dorsal CPu}
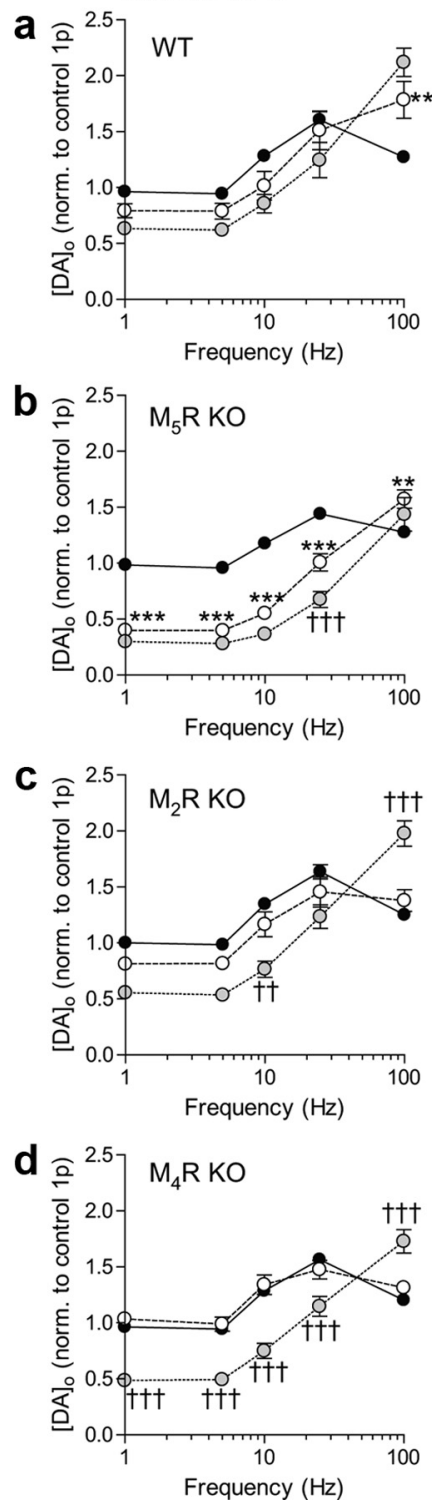
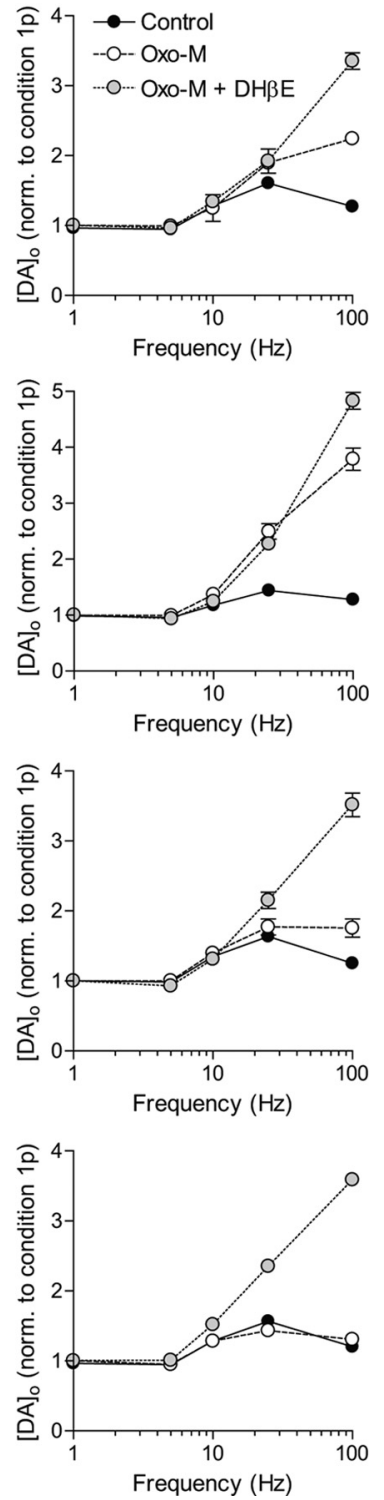

Figure 5. $M_{2} R s$ and $M_{4} R s$ are required for $m A C h R$ control of DA release in dorsal CPu. $a-d$, Mean peak $[D A]_{0} \pm$ SEM versus frequency in (Pu during four pulse trains $(1-100 \mathrm{~Hz})$ in control conditions (filled circles) or $0 \times 0-M$ (unfilled) or $0 \times 0-M$ plus $\mathrm{DH} \beta \mathrm{E}$ (gray fill) normalized to $[\mathrm{DA}]_{0}$ released by a single pulse in control conditions (left) or own condition (right), in wild types (WT) (a), $M_{5} R$-knock-outs ( $\left.M_{5} R K O\right)(\boldsymbol{b}), M_{2} R$-knock-outs $\left(M_{2} R K O\right)$ ( $\boldsymbol{c}$ ), and $M_{4} R$-knock-outs ( $\left.M_{4} R K O\right)$ (d) $(n=9-19)$. The asterisks indicate significance level in post hoc Bonferroni's $t$ tests for $0 \times 0$-M versus controls: ${ }^{* *} p<0.01,{ }^{* * *} p<0.001$. The daggers indicate significance level in Bonferroni's post hoc $t$ tests for $0 \times 0-\mathrm{M}$ versus $0 \times 0-\mathrm{M}$ plus $\mathrm{DH} \beta \mathrm{E}:{ }^{{ }^{+\dagger}} p<0.01,{ }^{\mathrm{t+}} p<0.001$. Significance levels for comparison of $0 \mathrm{x} 0-\mathrm{M}$ plus $\mathrm{DH} \beta \mathrm{E}$ versus control, or for data in right-hand panels, are omitted for clarity. $\boldsymbol{a}, \boldsymbol{b}$, In wild types and $\mathrm{M}_{5} \mathrm{R}$-nulls, $0 \mathrm{x}_{0}-\mathrm{M}$ significantly modifies evoked $[D A]_{0}$ in an activity-dependent manner, whereas additional application of $\mathrm{DH} \beta \mathrm{E}$ only slightly modifies evoked [DA] further $(n=9)$. $\boldsymbol{c}, \boldsymbol{d}$, In $\mathrm{M}_{2} \mathrm{R}-\mathrm{KO}$ or $\mathrm{M}_{4} \mathrm{R}-\mathrm{KO}, 0$, xo-M does not significantly modify evoked $[D A]_{0}$, but subsequent addition of $\mathrm{DH} \beta \mathrm{E}$ does modify $[D A]_{0}$ in a marked and significant, activity-dependent manner $(n=15-19)$.

example at greater temperatures or during phasic burst-like excitation in ChIs that can accompany salient stimuli (Ravel et al., 2003; Morris et al., 2004).

These data offer support generally for the hypothesis that the outcome of changes in DA neuron activity will depend critically on any accompanying changes in ChIs. Mesostriatal dopaminergic neurons and striatal ChIs both signal information about salient contextual stimuli through dynamic and temporally
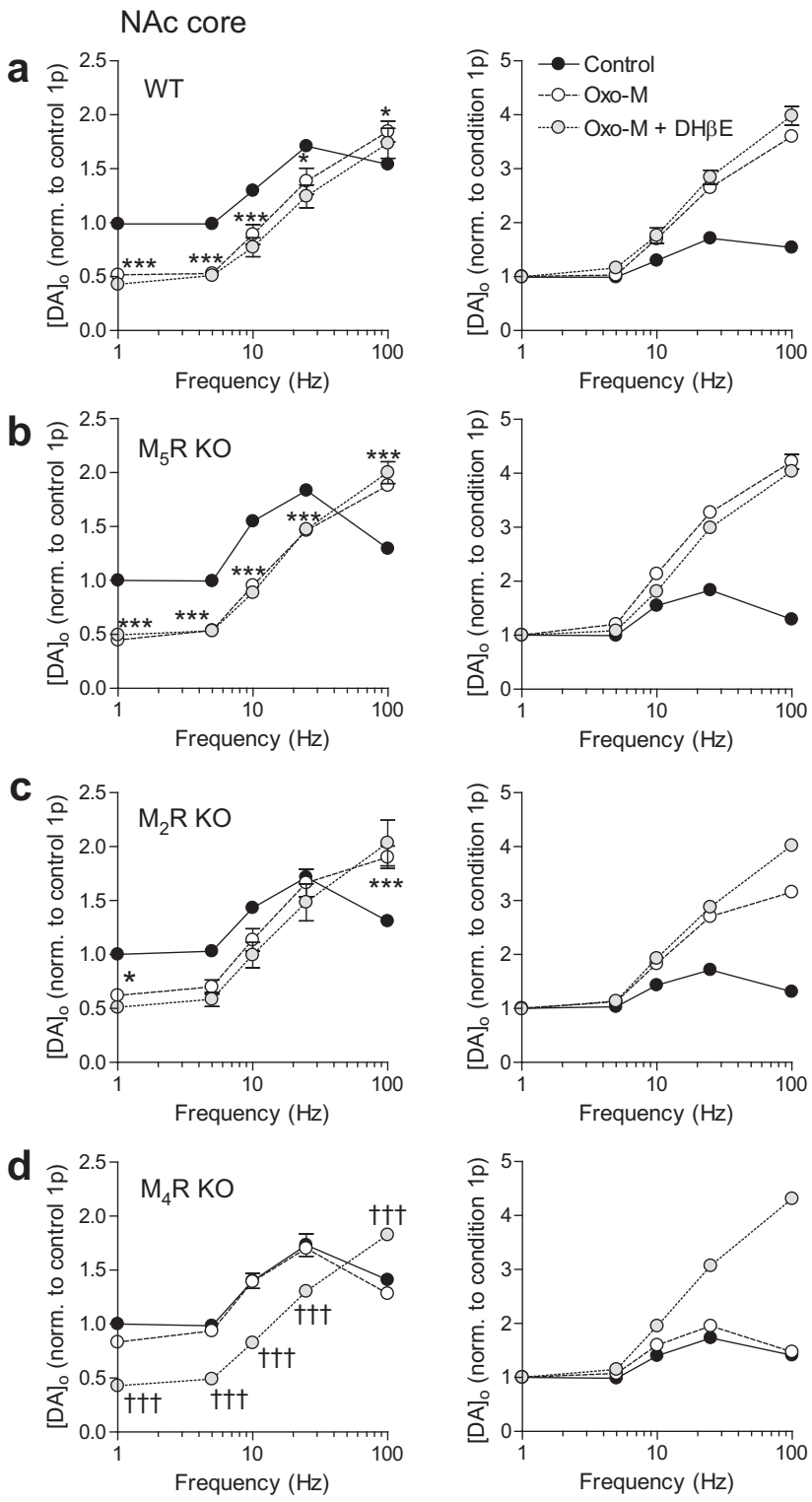

Figure 6. $M_{4} R s$ (and not $M_{2} R s$ ) are required for $m A C h R$ control of $D A$ release in NAc core. $\boldsymbol{a}-\boldsymbol{d}$, Mean peak $[D A]_{0} \pm$ SEM versus frequency in NAc core during four pulse trains $(1-100 \mathrm{~Hz})$ in control conditions (filled circles) or $0 \times 0-M$ (unfilled) or $0 \times 0-M$ plus $\mathrm{DH} \beta \mathrm{E}$ (gray fill) normalized to $[D A]_{0}$ released by a single pulse in control conditions (left) or own condition (right), in wild types (WT) $(\boldsymbol{a}), M_{5} R$-knock-outs $\left(M_{5} R\right.$ KO) $(\boldsymbol{b}), M_{2} R$-knock-outs $\left(M_{2} R K O\right)(\boldsymbol{c})$, and $M_{4} R-$ knock-outs $\left(M_{4} R K O\right)(d)(n=9-12)$. The asterisks indicate significance level in post hoc $t$ tests for $0 x_{0}-M$ versus controls: ${ }^{*} p<0.05,{ }^{* * *} p<0.001$. The daggers indicate significance level in post hoc $t$ tests for $0 \times 0-\mathrm{M}$ versus $0 \mathrm{x} 0-\mathrm{M}$ plus $\mathrm{DH} \beta \mathrm{E}:{ }^{\mathrm{tt}} p<0.001$. Significance levels for comparison of $0 \times 0-M$ plus $\mathrm{DH} \beta$ E versus control, or for data in right-hand panels, are omitted for clarity. $\boldsymbol{a}$ - $\boldsymbol{c}$, In wild types, $\mathrm{M}_{5} \mathrm{R}-\mathrm{KO}$, or $\mathrm{M}_{2} \mathrm{R}-\mathrm{K} 0,0 \times 0$-M significantly modifies evoked $[D A]_{0}$ in an activity-dependent manner and additional application of $\mathrm{DH} \beta \mathrm{E}$ does not modify evoked $[D A]_{0}$ further $(n=9-12)$. $\boldsymbol{d}$, In $\mathrm{M}_{4} \mathrm{R}-\mathrm{KO}, 0 \times 0-\mathrm{M}$ does not modify evoked [DA] $]_{0}$, but subsequent addition of $\mathrm{DH} \beta \mathrm{E}$ modifies $[\mathrm{DA}]_{0}$ in a marked and significant, activitydependent manner $(n=12)$.

coincident changes in their firing activity (Morris et al., 2004). Unexpected primary reinforcers, conditioned reinforcementpredicting cues and other salient stimuli are signaled by mesostriatal dopaminergic neurons by brief burst firing (Hyland et al., 2002; Schultz, 2002; Morris et al., 2004; Brischoux et al., 2009; Matsumoto and Hikosaka, 2009), whereas simultaneously striatal ChIs typically pause (sometimes within triphasic template comprising preexcitation, pause, and postexcitation) (Aosaki et 

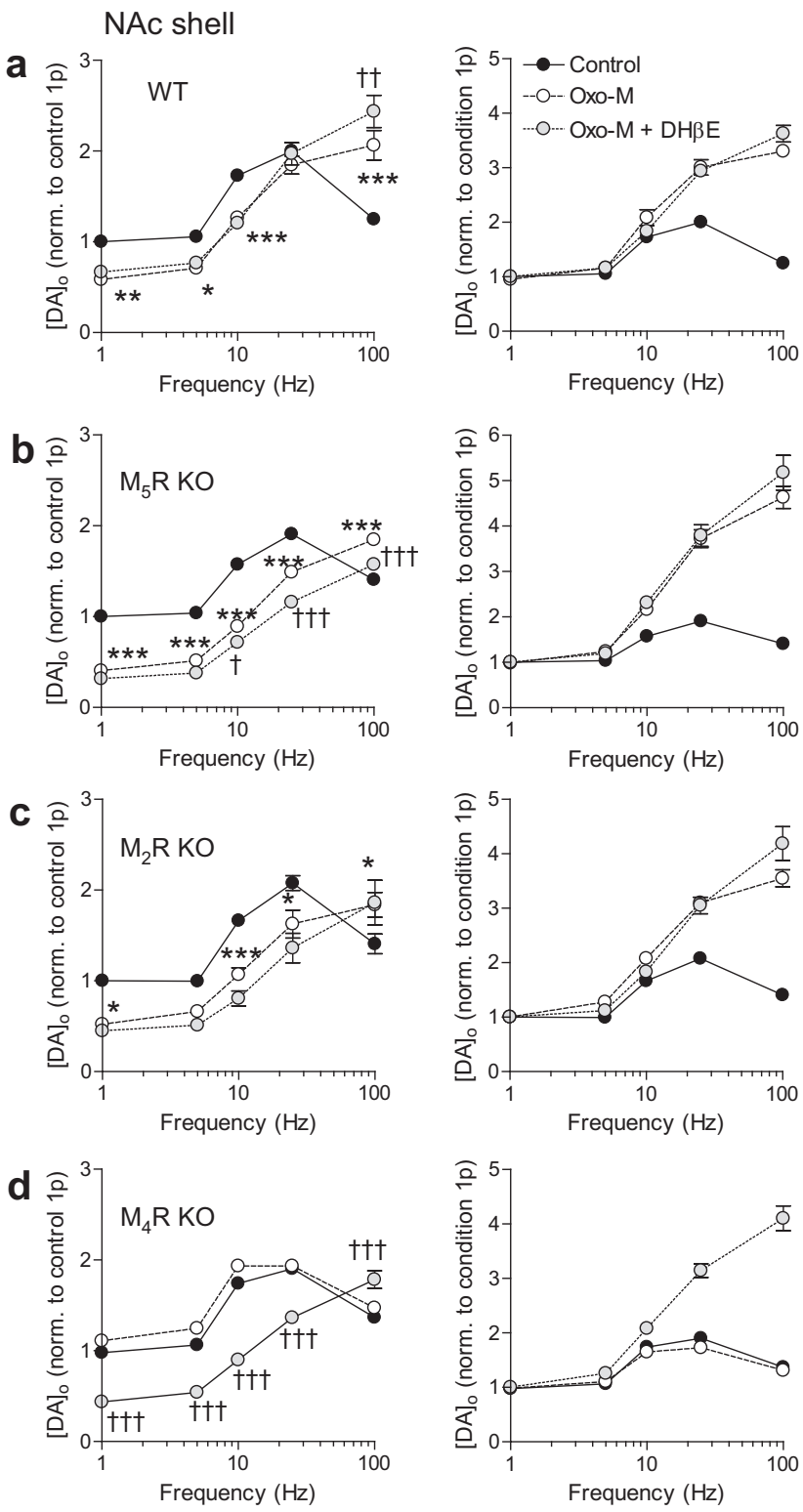

Figure 7. $M_{4} R s$ (and not $M_{2} R s$ ) are required for $m A C h R$ control of $D A$ release in NAc shell. $\boldsymbol{a}-\boldsymbol{d}$, Mean peak $[D A]_{0} \pm$ SEM versus frequency in NAc shell during four pulse trains $(1-100 \mathrm{~Hz})$ in control conditions (filled circles) or 0x0-M (unfilled) or $0 \times 0-M$ plus DH $\beta E$ (gray fill) normalized to $[D A]_{0}$ released by a single pulse in control conditions (left) or own condition (right), in wild types (WT) (a), $M_{5} R$-knock-outs $\left(M_{5} R K O\right)(\boldsymbol{b}), M_{2} R$-knock-outs $\left(M_{2} R K O\right)(\boldsymbol{c})$, and $M_{4} R-$ knock-outs $\left(M_{4} R K O\right)(d)(n=9)$. The asterisks indicate significance level in post hoc $t$ tests for $0 \times 0$-M versus controls: ${ }^{*} p<0.05,{ }^{* *} p<0.01,{ }^{* *} p<0.001$. The daggers indicate significance level in post hoc $t$ tests for $0 \mathrm{x} 0-\mathrm{M}$ versus $0 \mathrm{x} 0-\mathrm{M}$ plus $\mathrm{DH} \beta \mathrm{E}:{ }^{\dagger} p<0.05,{ }^{{ }^{\dagger}} p<0.01$, ${ }^{+t+} p<0.001$. Significance levels for comparison of $0 \times 0-M$ plus DH $\beta$ E versus control, or for data in right-hand panels, are omitted for clarity. $\boldsymbol{a}-\boldsymbol{c}$, In wild types, $\mathrm{M}_{5} \mathrm{R}-\mathrm{KO}$, or $\mathrm{M}_{2} \mathrm{R}-\mathrm{KO}, 0 \times 0-\mathrm{M}$ significantly modifies evoked $[D A]_{0}$ in an activity-dependent manner, and additional application of $\mathrm{DH} \beta$ E only slightly modifies evoked $[\mathrm{DA}]_{0}$ further $(n=9)$. $\boldsymbol{d}$, In $\mathrm{M}_{4} \mathrm{R}-\mathrm{KO}, 0 \mathrm{xO}$-M does not modify evoked $[D A]_{0}$, but subsequent addition of $\mathrm{DH} \beta \mathrm{E}$ modifies $[\mathrm{DA}]_{0}$ in a marked and significant, activity-dependent manner $(n=9)$.

al., 1994; Shimo and Hikosaka, 2001; Ravel et al., 2001, 2003; Apicella, 2002; Morris et al., 2004). Since mAChR activation apparently limits $\beta 2^{\star}$-nAChR activation, it may mimic the effects of a pause in ChI activity. Thus, these data support the hypothesis that pauses in ChIs enhance the sensitivity of DA synapses to temporally correlated changes in dopamine neuron activity and thus modify the salience of DA signals (Zhou et al., 2002; Cragg,
2006). Interestingly, animals may self-administer muscarinic agonists into NAc (Ikemoto et al., 1998).

\section{Distinct $\mathrm{M}_{2}$ - and/or $\mathrm{M}_{4}-\mathrm{mAChRs}$ govern DA release in $\mathrm{CPu}$ and NAc}

mAChR antagonists himbacine and tropicamide, at concentrations selective for $\mathrm{M}_{2} / \mathrm{M}_{4}$-mAChRs, competed with the effects of $\mathrm{mAChR}$ agonists, implicating $\mathrm{M}_{2} / \mathrm{M}_{4}$-type $\mathrm{mAChRs}$ throughout striatum. This finding is consistent with the expression of $\mathrm{M}_{2} /$ $\mathrm{M}_{4}$-mAChRs by ChIs (Yan and Surmeier, 1996; Bernard et al., 1998; Alcantara et al., 2001; Ding et al., 2006; Bonsi et al., 2008). However, several pieces of data suggested differing $\mathrm{M}_{2} / \mathrm{M}_{4}$ function between striatal territories. Lower concentrations of oxotremorine- $\mathrm{M}$ modified $\mathrm{DA}$ release in NAc than $\mathrm{CPu}$, indicating a mechanism of greater efficacy in NAc. Furthermore, whereas knock-out of the $\mathrm{M}_{4} \mathrm{R}$ prevented $\mathrm{mAChR}$ effects throughout striatum, knock-out of $\mathrm{M}_{2}$ Rs prevented $\mathrm{mAChR}$ control of DA release only in $\mathrm{CPu}$.

These data suggest that $\mathrm{M}_{4}$ Rs are necessary for $\mathrm{mAChR}$ regulation of DA (and $\mathrm{ACh}$ ) release throughout the striatum but that $\mathrm{M}_{2}$ Rs are necessary only in $\mathrm{CPu}$, where both $\mathrm{M}_{4}$ Rs and $\mathrm{M}_{2}$ Rs are required. In support of these observations, striatal $M_{4} R s$ have been suggested to autoinhibit ACh release (Bymaster et al., 2003), and in $\mathrm{CPu}$, both $\mathrm{M}_{4} \mathrm{Rs}$ and $\mathrm{M}_{2} \mathrm{Rs}$ mediate oxotremorineinduced reduction in excitability in ChIs in dorsal striatum (Bonsi et al., 2008). Comparative data for NAc are unavailable. Our data suggest that in $\mathrm{CPu}$ it is necessary to activate combined $\mathrm{M}_{2}$ and $\mathrm{M}_{4}$ populations of $\mathrm{mAChRs}$ to decrease ACh tone at $\beta 2^{\star}$-nAChRs sufficiently to modify DA release. In contrast in NAc, $M_{4}$ Rs (but not $M_{2}$ Rs) appear sufficiently well coupled to the control of ACh tone at $\beta 2^{\star}-\mathrm{nAChRs}$ to modify DA release. It is currently unknown whether these differences are attributable to different expression/role of $\mathrm{M}_{4}$ Rs versus $\mathrm{M}_{2}$ Rs in ChIs that supply each territory, or a different basal ACh tone at $\beta 2^{\star}$-nAChRs, or whether there are other intrinsic regional differences in ChIs, including compensatory adaptations that can accommodate loss of $\mathrm{M}_{2} \mathrm{Rs}$ in NAc but not in $\mathrm{CPu}$. Although there is no comparative study of expression/function of mAChRs in regulating ChI activity in each territory and no evidence for a difference in the levels of ACh reaching $\beta 2^{\star}$-nAChRs (Exley et al., 2008), there are, however, reports that $\mathrm{mAChRs}$ are found at higher levels in ventral than dorsal striatum in rats (Tayebati et al., 2004) and that ChIs in limbic/prefrontal versus sensorimotor territories express different levels of other types of receptors ( $\mu$-opioid) (Jabourian et al., 2005). Thus, distinct muscarinic mechanisms/receptors in subpopulations of ChIs may explain the differing $\mathrm{mAChR}$ control of DA release in $\mathrm{CPu}$ and NAc. These regional differences in $\mathrm{M}_{2} / \mathrm{M}_{4}$ function could ultimately be exploited for discrete modulation of DA/ACh. For example, ACh/DA function might be modified selectively in NAc by activation of $M_{4} R s$, and in $\mathrm{CPu}$ by $\mathrm{M}_{2} \mathrm{R}$ inhibition.

\section{Summary and conclusions}

These data reveal that striatal $\mathrm{M}_{2}$ - and/or $\mathrm{M}_{4}$-mAChRs on ChIs offer powerful, activity-dependent regulation of DA release. By reducing ACh tone at $\beta 2^{*}-\mathrm{nAChRs}$, mAChRs promote the sensitivity of DA synapses to presynaptic activity. In turn, these data suggest that physiological pauses in activity in ChIs (e.g., reinforcement-related) promote the activity dependence of DA signaling. Discrete targeting of $\mathrm{M}_{4}$ Rs or $\mathrm{M}_{2}$ Rs could allow selective modulation of DA/ACh function in NAc or CPu. Striatal $\mathrm{mAChRs}$ on ChIs have been proposed as a useful future target to decrease net striatal ACh function (Pisani et al., 2007). These data 
show that they will simultaneously modify DA signaling and may thus be useful targets for the therapeutic management of goaldirected behavior and reinforcement processing in striatal disorders including Parkinson's disease, dystonias, as well as drug addiction.

\section{References}

Abeliovich A, Schmitz Y, Fariñas I, Choi-Lundberg D, Ho WH, Castillo PE, Shinsky N, Verdugo JM, Armanini M, Ryan A, Hynes M, Phillips H, Sulzer D, Rosenthal A (2000) Mice lacking alpha-synuclein display functional deficits in the nigrostriatal dopamine system. Neuron 25: $239-252$.

Alcantara AA, Mrzljak L, Jakab RL, Levey AI, Hersch SM, Goldman-Rakic PS (2001) Muscarinic $\mathrm{m} 1$ and $\mathrm{m} 2$ receptor proteins in local circuit and projection neurons of the primate striatum: anatomical evidence for cholinergic modulation of glutamatergic prefronto-striatal pathways. J Comp Neurol 434:445-460.

Aosaki T, Tsubokawa H, Ishida A, Watanabe K, Graybiel AM, Kimura M (1994) Responses of tonically active neurons in the primate's striatum undergo systematic changes during behavioral sensorimotor conditioning. J Neurosci 14:3969-3984.

Apicella P (2002) Tonically active neurons in the primate striatum and their role in the processing of information about motivationally relevant events. Eur J Neurosci 16:2017-2026.

Avshalumov MV, Chen BT, Marshall SP, Peña DM, Rice ME (2003) Glutamate-dependent inhibition of dopamine release in striatum is mediated by a new diffusible messenger, $\mathrm{H}_{2} \mathrm{O}_{2}$. J Neurosci 23:2744-2750.

Bennett BD, Wilson CJ (1999) Spontaneous activity of neostriatal cholinergic interneurons in vitro. J Neurosci 19:5586-5596.

Bernard V, Normand E, Bloch B (1992) Phenotypical characterization of the rat striatal neurons expressing muscarinic receptor genes. J Neurosci 12:3591-3600.

Bernard V, Laribi O, Levey AI, Bloch B (1998) Subcellular redistribution of $\mathrm{m} 2$ muscarinic acetylcholine receptors in striatal interneurons in vivo after acute cholinergic stimulation. J Neurosci 18:10207-10218.

Bonsi P, Martella G, Cuomo D, Platania P, Sciamanna G, Bernardi G, Wess J, Pisani A (2008) Loss of muscarinic autoreceptor function impairs longterm depression but not long-term potentiation in the striatum. J Neurosci 28:6258-6263.

Brischoux F, Chakraborty S, Brierley DI, Ungless MA (2009) Phasic excitation of dopamine neurons in ventral VTA by noxious stimuli. Proc Natl Acad Sci U S A 106:4894-4899.

Britt JP, McGehee DS (2008) Presynaptic opioid and nicotinic receptor modulation of dopamine overflow in the nucleus accumbens. J Neurosci 28:1672-1681.

Bymaster FP, McKinzie DL, Felder CC, Wess J (2003) Use of M1-M5 muscarinic receptor knockout mice as novel tools to delineate the physiological roles of the muscarinic cholinergic system. Neurochem Res 28:437-442.

Calabresi P, Centonze D, Pisani A, Sancesario G, North RA, Bernardi G (1998a) Muscarinic IPSPs in rat striatal cholinergic interneurones. J Physiol 510:421-427.

Calabresi P, Centonze D, Gubellini P, Pisani A, Bernardi G (1998b) Endogenous ACh enhances striatal NMDA-responses via M1-like muscarinic receptors and PKC activation. Eur J Neurosci 10:2887-2895.

Calabresi P, Centonze D, Gubellini P, Pisani A, Bernardi G (1998c) Blockade of M2-like muscarinic receptors enhances long-term potentiation at corticostriatal synapses. Eur J Neurosci 10:3020-3023.

Calabresi P, Centonze D, Gubellini P, Pisani A, Bernardi G (2000) Acetylcholine-mediated modulation of striatal function. Trends Neurosci 23:120-126.

Centonze D, Gubellini P, Pisani A, Bernardi G, Calabresi P (2003) Dopamine, acetylcholine and nitric oxide systems interact to induce corticostriatal synaptic plasticity. Rev Neurosci 14:207-216.

Cragg SJ (2003) Variable dopamine release probability and short-term plasticity between functional domains of the primate striatum. J Neurosci 23:4378-4385

Cragg SJ (2006) Meaningful silences: how dopamine listens to the ACh pause. Trends Neurosci 29:125-131.

Cragg SJ, Greenfield SA (1997) Differential autoreceptor control of somatodendritic and axon terminal dopamine release in substantia nigra, ventral tegmental area, and striatum. J Neurosci 17:5738-5746. de Fiebre CM, Meyer EM, Henry JC, Muraskin SI, Kem WR, Papke RL (1995) Characterization of a series of anabaseine-derived compounds reveals that the 3-(4)-dimethylaminocinnamylidine derivative is a selective agonist at neuronal nicotinic alpha $7 /{ }^{125} \mathrm{I}$-alpha-bungarotoxin receptor subtypes. Mol Pharmacol 47:164-171.

De Klippel N, Sarre S, Ebinger G, Michotte Y (1993) Effect of M1- and M2-muscarinic drugs on striatal dopamine release and metabolism: an in vivo microdialysis study comparing normal and 6-hydroxydopaminelesioned rats. Brain Res 630:57-64.

Ding J, Guzman JN, Tkatch T, Chen S, Goldberg JA, Ebert PJ, Levitt P, Wilson CJ, Hamm HE, Surmeier DJ (2006) RGS4-dependent attenuation of M4 autoreceptor function in striatal cholinergic interneurons following dopamine depletion. Nat Neurosci 9:832-842.

Exley R, Cragg SJ (2008) Presynaptic nicotinic receptors: a dynamic and diverse cholinergic filter of striatal dopamine neurotransmission. Br J Pharmacol 153 [Suppl 1]:S283-S297.

Exley R, Clements MA, Hartung H, McIntosh JM, Cragg SJ (2008) Alpha6containing nicotinic acetylcholine receptors dominate the nicotine control of dopamine neurotransmission in nucleus accumbens. Neuropsychopharmacology 33:2158-2166.

Forster GL, Yeomans JS, Takeuchi J, Blaha CD (2002) $\mathrm{M}_{5}$ muscarinic receptors are required for prolonged accumbal dopamine release after electrical stimulation of the pons in mice. J Neurosci 22:RC190(1-6).

Fujiyama F, Fritschy JM, Stephenson FA, Bolam JP (2000) Synaptic localization of $\mathrm{GABA}_{\mathrm{A}}$ receptor subunits in the striatum of the rat. J Comp Neurol 416:158-172.

Gomeza J, Shannon H, Kostenis E, Felder C, Zhang L, Brodkin J, Grinberg A, Sheng H, Wess J (1999a) Pronounced pharmacologic deficits in M2 muscarinic acetylcholine receptor knockout mice. Proc Natl Acad Sci U S A 96:1692-1697.

Gomeza J, Zhang L, Kostenis E, Felder C, Bymaster F, Brodkin J, Shannon H, Xia B, Deng C, Wess J (1999b) Enhancement of D1 dopamine receptormediated locomotor stimulation in $\mathrm{M}_{4}$ muscarinic acetylcholine receptor knockout mice. Proc Natl Acad Sci U S A 96:10483-10488.

Grilli M, Patti L, Robino F, Zappettini S, Raiteri M, Marchi M (2008) Release-enhancing pre-synaptic muscarinic and nicotinic receptors coexist and interact on dopaminergic nerve endings of rat nucleus accumbens. J Neurochem 105:2205-2213.

Hersch SM, Gutekunst CA, Rees HD, Heilman CJ, Levey AI (1994) Distribution of $\mathrm{m} 1-\mathrm{m} 4$ muscarinic receptor proteins in the rat striatum: light and electron microscopic immunocytochemistry using subtype-specific antibodies. J Neurosci 14:3351-3363.

Hyland BI, Reynolds JN, Hay J, Perk CG, Miller R (2002) Firing modes of midbrain dopamine cells in the freely moving rat. Neuroscience 114:475-492.

Ikemoto S, Glazier BS, Murphy JM, McBride WJ (1998) Rats selfadminister carbachol directly into the nucleus accumbens. Physiol Behav 63:811-814.

Jabourian M, Venance L, Bourgoin S, Ozon S, Pérez S, Godeheu G, Glowinski J, Kemel ML (2005) Functional mu opioid receptors are expressed in cholinergic interneurons of the rat dorsal striatum: territorial specificity and diurnal variation. Eur J Neurosci 21:3301-3309.

Jakubík J, Bacáková L, El-Fakahany EE, Tucek S (1997) Positive cooperativity of acetylcholine and other agonists with allosteric ligands on muscarinic acetylcholine receptors. Mol Pharmacol 52:172-179.

Jones IW, Bolam JP, Wonnacott S (2001) Presynaptic localisation of the nicotinic acetylcholine receptor beta2 subunit immunoreactivity in rat nigrostriatal dopaminergic neurones. J Comp Neurol 439:235-247.

Karlsson E, Jolkkonen M, Mulugeta E, Onali P, Adem A (2000) Snake toxins with high selectivity for subtypesof muscarinic acetylcholine receptors. Biochimie 82:793-806.

Kemel ML, Desban M, Glowinski J, Gauchy C (1989) Distinct presynaptic control of dopamine release in striosomal and matrix areas of the cat caudate nucleus. Proc Natl Acad Sci U S A 86:9006-9010.

Koós T, Tepper JM (2002) Dual cholinergic control of fast-spiking interneurons in the neostriatum. J Neurosci 22:529-535.

Kudernatsch M, Sutor B (1994) Cholinergic modulation of dopamine overflow in the rat neostriatum: a fast cyclic voltammetric study in vitro. Neurosci Lett 181:107-112.

Lehmann J, Langer SZ (1982) Muscarinic receptors on dopamine terminals in the cat caudate nucleus: neuromodulation of $\left[{ }^{3} \mathrm{H}\right]$ dopamine release in vitro by endogenous acetylcholine. Brain Res 248:61-69. 
Levey AI, Kitt CA, Simonds WF, Price DL, Brann MR (1991) Identification and localization of muscarinic acetylcholine receptor proteins in brain with subtype-specific antibodies. J Neurosci 11:3218-3226.

Matsumoto M, Hikosaka O (2009) Two types of dopamine neuron distinctly convey positive and negative motivational signals. Nature 459: 837-841.

Morris G, Arkadir D, Nevet A, Vaadia E, Bergman H (2004) Coincident but distinct messages of midbrain dopamine and striatal tonically active neurons. Neuron 43:133-143.

Pakhotin P, Bracci E (2007) Cholinergic interneurons control the excitatory input to the striatum. J Neurosci 27:391-400.

Partridge JG, Apparsundaram S, Gerhardt GA, Ronesi J, Lovinger DM (2002) Nicotinic acetylcholine receptors interact with dopamine in induction of striatal long-term depression. J Neurosci 22:2541-2549.

Phillips PE, Hancock PJ, Stamford JA (2002) Time window of autoreceptormediated inhibition of limbic and striatal dopamine release. Synapse 44:15-22.

Pisani A, Bonsi P, Centonze D, Gubellini P, Bernardi G, Calabresi P (2003) Targeting striatal cholinergic interneurons in Parkinson's disease: focus on metabotropic glutamate receptors. Neuropharmacology 45:45-56.

Pisani A, Bernardi G, Ding J, Surmeier DJ (2007) Re-emergence of striatal cholinergic interneurons in movement disorders. Trends Neurosci 30:545-553

Raiteri M, Leardi R, Marchi M (1984) Heterogeneity of presynaptic muscarinic receptors regulating neurotransmitter release in the rat brain. J Pharmacol Exp Ther 228:209-214.

Ravel S, Sardo P, Legallet E, Apicella P (2001) Reward unpredictability inside and outside of a task context as a determinant of the responses of tonically active neurons in the monkey striatum. J Neurosci 21:57305739.

Ravel S, Legallet E, Apicella P (2003) Responses of tonically active neurons in the monkey striatum discriminate between motivationally opposing stimuli. J Neurosci 23:8489-8497.

Rice ME, Cragg SJ (2004) Nicotine amplifies reward-related dopamine signals in striatum. Nat Neurosci 7:583-584.

Schmitz Y, Schmauss C, Sulzer D (2002) Altered dopamine release and uptake kinetics in mice lacking $\mathrm{D}_{2}$ receptors. J Neurosci 22:8002-8009.

Schoffelmeer AN, Van Vliet BJ, Wardeh G, Mulder AH (1986) Muscarine receptor-mediated modulation of $\left[{ }^{3} \mathrm{H}\right]$ dopamine and $\left[{ }^{14} \mathrm{C}\right]$ acetylcholine release from rat neostriatal slices: selective antagonism by gallamine but not pirenzepine. Eur J Pharmacol 128:291-294.

Schultz W (1986) Responses of midbrain dopamine neurons to behavioral trigger stimuli in the monkey. J Neurophysiol 56:1439-1461.

Schultz W (1998) Predictive reward signal of dopamine neurons. J Neurophysiol 80:1-27.

Schultz W (2002) Getting formal with dopamine and reward. Neuron $36: 241-263$.

Shimo Y, Hikosaka O (2001) Role of tonically active neurons in primate caudate in reward-oriented saccadic eye movement. J Neurosci 21:78047814.

Sugita S, Uchimura N, Jiang ZG, North RA (1991) Distinct muscarinic receptors inhibit release of gamma-aminobutyric acid and excitatory amino acids in mammalian brain. Proc Natl Acad Sci U S A 88:2608-2611.

Tayebati SK, Di Tullio MA, Amenta F (2004) Age-related changes of muscarinic cholinergic receptor subtypes in the striatum of Fisher 344 rats. Exp Gerontol 39:217-223.
Thomson AM (2000) Molecular frequency filters at central synapses. Prog Neurobiol 62:159-196.

Tzavara ET, Bymaster FP, Davis RJ, Wade MR, Perry KW, Wess J, McKinzie DL, Felder C, Nomikos GG (2004) M4 muscarinic receptors regulate the dynamics of cholinergic and dopaminergic neurotransmission: relevance to the pathophysiology and treatment of related CNS pathologies. FASEB J 18:1410-1412.

Venton BJ, Michael DJ, Wightman RM (2003) Correlation of local changes in extracellular oxygen and $\mathrm{pH}$ that accompany dopaminergic terminal activity in the rat caudate-putamen. J Neurochem 84:373-381.

Vilaró MT, Palacios JM, Mengod G (1990) Localization of m5 muscarinic receptor mRNA in rat brain examined by in situ hybridization histochemistry. Neurosci Lett 114:154-159.

Weiner DM, Levey AI, Brann MR (1990) Expression of muscarinic acetylcholine and dopamine receptor mRNAs in rat basal ganglia. Proc Natl Acad Sci U S A 87:7050-7054.

Wess J, Eglen RM, Gautam D (2007) Muscarinic acetylcholine receptors: mutant mice provide new insights for drug development. Nat Rev Drug Discov 6:721-733.

Whiteaker P, Sharples CG, Wonnacott S (1998) Agonist-induced upregulation of alpha4beta2 nicotinic acetylcholine receptors in M10 cells: pharmacological and spatial definition. Mol Pharmacol 53:950-962.

Xu M, Mizobe F, Yamamoto T, Kato T (1989) Differential effects of M1and M2-muscarinic drugs on striatal dopamine release and metabolism in freely moving rats. Brain Res 495:232-242.

Yamada M, Lamping KG, Duttaroy A, Zhang W, Cui Y, Bymaster FP, McKinzie DL, Felder CC, Deng CX, Faraci FM, Wess J (2001) Cholinergic dilation of cerebral blood vessels is abolished in $\mathrm{M}_{5}$ muscarinic acetylcholine receptor knockout mice. Proc Natl Acad Sci U S A 98:14096-14101.

Yan Z, Surmeier DJ (1996) Muscarinic (m2/m4) receptors reduce N- and $\mathrm{P}$-type $\mathrm{Ca}^{2+}$ currents in rat neostriatal cholinergic interneurons through a fast, membrane-delimited, G-protein pathway. J Neurosci 16:25922604.

Yan Z, Flores-Hernandez J, Surmeier DJ (2001) Coordinated expression of muscarinic receptor messenger RNAs in striatal medium spiny neurons. Neuroscience 103:1017-1024.

Zhang H, Sulzer D (2004) Frequency-dependent modulation of dopamine release by nicotine. Nat Neurosci 7:581-582.

Zhang W, Basile AS, Gomeza J, Volpicelli LA, Levey AI, Wess J (2002a) Characterization of central inhibitory muscarinic autoreceptors by the use of muscarinic acetylcholine receptor knock-out mice. J Neurosci 22:1709-1717.

Zhang W, Yamada M, Gomeza J, Basile AS, Wess J (2002b) Multiple muscarinic acetylcholine receptor subtypes modulate striatal dopamine release, as studied with $\mathrm{M}_{1}-\mathrm{M}_{5}$ muscarinic receptor knock-out mice. J Neurosci 22:6347-6352.

Zhou FM, Liang Y, Dani JA (2001) Endogenous nicotinic cholinergic activity regulates dopamine release in the striatum. Nat Neurosci 4:12241229.

Zhou FM, Wilson CJ, Dani JA (2002) Cholinergic interneuron characteristics and nicotinic properties in the striatum. J Neurobiol 53:590-605.

Zhou FM, Wilson C, Dani JA (2003) Muscarinic and nicotinic cholinergic mechanisms in the mesostriatal dopamine systems. Neuroscientist 9:23-36. 